\title{
WATER POLLUTION IN LAKE MICHIGAN BY TRACE ELEMENTS FROM POLLUTION AEROSOL FALLOUT
}

\author{
JOHN W. WINCHESTER* and GORDON D. NIFONG** \\ The University of Michigan, Ann Arbor, Michigan 48104, U.S.A.
}

(Received 1 April, 1971)

\begin{abstract}
Certain trace elements which are strongly associated with air pollution sources in the Lake Michigan basin may be contributing significantly to lake water pollution by an atmospheric fallout route. In this paper a partial inventory of air pollution emissions for 30 trace elements is presented for the Chicago, Milwaukee, and northwest Indiana metropolitan areas, based on available published information. The inventory is then compared with actual stream inputs measured for $\mathrm{Zn}, \mathrm{Cu}$, and $\mathrm{Ni}$ and with estimates of pre-industrial unpolluted stream inputs for 28 elements. Evidence indicates that the atmosphere may now be a major source of $\mathrm{Zn}$ in Lake Michigan, and atmospheric inputs of $\mathrm{Cu}$ and $\mathrm{Ni}$ may also be considerable. Moreover, the evidence suggests that air pollution probably exceeds expected unpolluted stream inputs for many additional elements in Lake Michigan, highlighting the need for more comprehensive chemical data to quantify the evaluation.
\end{abstract}

A chemical model for the trace element composition of a Great Lake, where sources and sinks of each element are evaluated and compared with the observed concentrations in the lake, must consider atmospheric as well as surface water sources. For Lake Michigan atmospheric inputs may be especially important since surface water inputs from the heavily populated and industrialized southern shore have been minimized by the construction of artificial drainage channels in the Chicago area (Bacon and Dalton, 1968). Consequently, air pollution, which is carried from the southern and western shore by prevailing westerly winds over the lake, may be a relatively large source of water pollution by fallout, impaction, rainout, or rainfall washout of the atmospheric aerosol over the lake itself.

A quantitative calculation of the air pollution contribution to lake water pollution requires an accurate estimate of trace element inputs to the atmosphere from various sources, but such an emissions inventory does not appear in the literature. If we knew mean atmospheric residence times of particulate matter from the various urban sources, we could utilize measurements of the average elemental composition of total suspended particulate in the steady-state urban atmosphere in making the calculation. However, residence times may be variable and depend on source location and particle size, among other factors. Therefore, it is more direct to construct an approximate table of trace element emissions resulting from the major air pollution sources in the Chicago area by combining published data on the composition of different particulate emissions with expected total emissions from the different sources. In this

\footnotetext{
* Now at: Dept. of Oceanography, Florida State University, Tallahassee, Florida 32306, U.S.A.

** Now at: Bethlehem Steel Corp., Bethlehem, Pennsylvania 18016, U.S.A.
} 
paper, such a preliminary trace element emissions inventory is presented, and its significance for Lake Michigan water pollution is discussed.

\section{Air Pollution Sources}

The population in millions and the percentage of the total in the region for three Standard Metropolitan Statistical Areas (U.S. Census Bureau, 1961) important in this study are: Chicago, $6.25(78 \%)$, northwest Indiana, $0.575(7 \%)$, and Milwaukee, $1.20(15 \%)$, total, 8.025. In the Chicago SMSA the population density is high, and air pollution from vehicular traffic and electric power production is considerable. Northwest Indiana has the largest concentration of iron and steel industry, and important inputs of trace elements characteristic of this type of source are expected. Milwaukee is a population center with a relative emission composition perhaps resembling that of Chicago.

The major sources of air pollution which contribute trace elements to the atmosphere over southern Lake Michigan are:

(1) Coal burned for electrical and heating uses.

(2) Emissions from coke ovens in the manufacture of metallurgical coke.

(3) Fuel oil burned for electrical and heating needs.

(4) Automotive fuel burned for transportation.

(5) Emissions from iron and steel manufacturing facilities.

(6) Emissions from cement manufacturing plants.

For each of these source types the probable composition was taken from the available published literature, and a source emission inventory of elements was computed. Details of the calculation are given in the appendix.

\section{Calculated and Measured Air Pollution Composition}

Table I presents a summary of emissions into the atmosphere of trace elements from the major sources in the Chicago, Milwaukee, and northwestern Indiana metropolitan areas. As a test of the adequacy of our air pollution estimates, we may compare this calculated composition with analyses of air pollution particulates by the National Air Sampling Network (1966). Spectrographic analyses were performed on standard high volume filter samples taken throughout 1964 in one central location in each Chicago, East Chicago, and Milwaukee. In Chicago the sampling location was considerably to the north of some important industrial sources. Likewise, in East Chicago the location was generally upwind in industrial sources and far enough away for some local fallout to occur between source and sampler, and we expect some bias as a result. However, for the area sources of coal, oil, and gasoline combustion, all three sampling locations may be representative.

Let us first compare our inventory with average elemental composition of suspended particulate matter during 1964 for Chicago, East Chicago, and Milwaukee, Table II (Air Quality Data, 1966). Also given is our inventory normalized to $\mathrm{Pb}=1$. (Note 
TABLE I

Calculated particulate emission of trace elements from air pollution sources in Chicago, Milwaukee, and Northwest Indiana considered in this study

\begin{tabular}{|c|c|c|c|c|c|c|c|c|}
\hline \multirow[t]{2}{*}{ Element } & \multicolumn{6}{|c|}{ Calculated source emission, short tons per year } & \multirow{2}{*}{$\begin{array}{l}\text { Total } \\
\text { short tons } \\
\text { per year }\end{array}$} & \multirow{2}{*}{$\begin{array}{l}\text { Total } \\
\text { kilograms } \\
\text { per year } \\
\left(\times 10^{3}\right)\end{array}$} \\
\hline & Coal & Coke & Fuel Oil & $\begin{array}{l}\text { Iron } \\
\text { and } \\
\text { steel }\end{array}$ & Cement & $\begin{array}{l}\text { Trans- } \\
\text { portation }\end{array}$ & & \\
\hline
\end{tabular}

\begin{tabular}{|c|c|c|c|c|c|c|c|}
\hline $\mathrm{Ag}$ & & & 3 & & & 3 & 3 \\
\hline $\mathrm{Al}$ & 40000 & 2800 & 955 & 4950 & 1000 & 50000 & 45000 \\
\hline As & 46 & 3 & & & & 49 & 44 \\
\hline B & & & 4 & & & 4 & 4 \\
\hline $\mathrm{Ba}$ & 176 & 12 & 45 & & & 230 & 210 \\
\hline $\mathrm{Be}$ & 5 & 1 & & & & 6 & 5 \\
\hline $\mathrm{Br}$ & & & & & 800 & 800 & 725 \\
\hline $\mathrm{Ca}$ & 10600 & 760 & 74 & 11600 & 17600 & 41000 & 37000 \\
\hline $\mathrm{Cd}$ & 12 & 1 & & & & 13 & 12 \\
\hline $\mathrm{C} 1$ & & & & & 700 & 700 & 635 \\
\hline Co & 25 & 2 & 28 & & & 55 & 50 \\
\hline $\mathrm{Cr}$ & 80 & 6 & 22 & & & 110 & 100 \\
\hline $\mathrm{Cu}$ & 109 & 8 & 28 & 3400 & & 3500 & 3200 \\
\hline $\mathrm{Fe}$ & 19500 & 1400 & 450 & 73000 & 930 & 95000 & 86000 \\
\hline K & & & 16 & & & 16 & 15 \\
\hline $\mathrm{Mg}$ & 2090 & 150 & 56 & 3360 & 500 & 6100 & 5500 \\
\hline $\mathrm{Mn}$ & 67 & 5 & 6 & 5000 & & 5100 & 4600 \\
\hline Mo & 45 & 3 & 3.4 & & & 51 & 46 \\
\hline $\mathrm{Na}$ & 1120 & 80 & 274 & & & 1500 & 1400 \\
\hline $\mathrm{Ni}$ & 109 & 8 & 1030 & & & 1100 & 1000 \\
\hline $\mathbf{P}$ & & & & 170 & & 170 & 150 \\
\hline $\mathrm{Pb}$ & 328 & 24 & 33 & & 2000 & 2400 & 2200 \\
\hline *S & 550000 & 40000 & 150000 & 1000 & 7000 & 750000 & 680000 \\
\hline $\mathrm{Se}$ & 5.5 & 0.4 & 15 & & 1 & 22 & 20 \\
\hline $\mathrm{Si}$ & 55800 & 4000 & 433 & 850 & 4000 & 65000 & 59000 \\
\hline Sn & 13 & 1 & & & & 14 & 13 \\
\hline $\mathrm{Sr}$ & & & 6 & & & 6 & 5 \\
\hline $\mathrm{Ti}$ & 2390 & 170 & 6 & & & 2600 & 2400 \\
\hline V & 209 & 15 & 450 & & & 670 & 610 \\
\hline $\mathrm{Zn}$ & 247 & 18 & 9 & 4000 & & 4300 & 3900 \\
\hline
\end{tabular}

* Total S (gaseous and particulate) included in order to calculate Se.

that the mean contents of $\mathrm{Pb}$ in suspended particulate matter are approximately equal to $1 \mu \mathrm{g} \mathrm{m}^{-3}$ of air.) It might be expected that similar ratios exist between concentrations of elements as found in the analyses of suspended particulate matter and that determined in the inventory if mean atmospheric residence times are similar. Indeed, within an order of magnitude, this is generally the case.

Let us examine in greater detail the relative composition of particulates originating individually from the major sources. The elements $\mathrm{Fe}, \mathrm{Mn}, \mathrm{Cu}$, and $\mathrm{Zn}$ are seen by our inventory in Table I to come primarily from the iron and steel industry, and their ratios may be compared with mean measured values in the three locations indicated in Table III. Agreement is satisfactory for the ratios $\mathrm{Fe} / \mathrm{Mn} / \mathrm{Cu}$ for all three locations 
TABLE II

Ambient air concentrations of elements and comparison with calculated emission inventory

\begin{tabular}{|c|c|c|c|c|}
\hline \multirow[t]{2}{*}{ Element } & \multicolumn{3}{|c|}{$\begin{array}{l}\text { Concentration in } \mu \mathrm{g} \mathrm{m}^{-3}, 1964 \\
\text { arithmetic mean }\end{array}$} & \multirow[t]{2}{*}{$\begin{array}{l}\text { Inventory } \\
\text { (normalized to } \mathrm{Pb}=1 \text { ) }\end{array}$} \\
\hline & Chicago & E. Chicago & Milwaukee & \\
\hline (Total particulate) & 176 & 218 & 146 & 80 \\
\hline $\mathrm{Ag}$ & & & & 0.001 \\
\hline $\mathrm{Al}$ & & & & 21 \\
\hline As & 0.03 & 0.04 & 0.02 & 0.02 \\
\hline B & & & & 0.002 \\
\hline $\mathrm{Ba}$ & & & & 0.10 \\
\hline $\mathrm{Be}$ & $<0.001$ & $<0.005$ & $<0.001$ & 0.003 \\
\hline $\mathrm{Br}$ & & & & 0.3 \\
\hline $\mathrm{Ca}$ & & & & 17 \\
\hline Cd & $<0.05$ & $<0.04$ & $<0.01$ & 0.005 \\
\hline $\mathrm{Cl}$ & & & & 0.3 \\
\hline Co & $<0.006$ & $<0.011$ & $<0.006$ & 0.02 \\
\hline $\mathrm{Cr}$ & 0.014 & 0.033 & 0.01 & 0.05 \\
\hline $\mathrm{Cu}$ & 0.04 & 0.12 & 0.06 & 1.5 \\
\hline $\mathrm{Fe}$ & 1.6 & 5.5 & 1.9 & 40 \\
\hline K & & & & 0.007 \\
\hline $\mathrm{Mg}$ & & & & 2.5 \\
\hline $\mathrm{Mn}$ & 0.07 & 0.28 & 0.12 & 2.1 \\
\hline Mo & $<0.01$ & $<0.16$ & $<0.03$ & 0.02 \\
\hline $\mathrm{Na}$ & & & & 0.6 \\
\hline $\mathrm{Ni}$ & 0.42 & 0.123 & 0.023 & 0.5 \\
\hline $\mathrm{P}$ & & & & 0.07 \\
\hline $\mathrm{Pb}$ & 0.9 & 0.9 & 0.5 & (1) \\
\hline $\mathbf{S}$ & & & & 300 \\
\hline $\mathrm{Se}$ & & & & 0.01 \\
\hline $\mathrm{Si}$ & & & & 30 \\
\hline Sn & 0.02 & 0.06 & 0.01 & 0.006 \\
\hline Sr & & & & 0.003 \\
\hline $\mathrm{Ti}$ & 0.02 & 0.05 & 0.05 & 1.1 \\
\hline $\mathrm{V}$ & 0.03 & 0.04 & 0.004 & 0.3 \\
\hline $\mathrm{Zn}$ & 0.95 & 2.57 & 0.16 & 1.8 \\
\hline
\end{tabular}

but for $\mathrm{Fe} / \mathrm{Zn}$ only approximately in one location, Milwaukee. The very high $\mathrm{Zn}$ values observed in Chicago and East Chicago suggest an additional pollution source not considered in our inventory, a gross underestimate of $\mathrm{Zn}$ in material from the sources included in our inventory, or analytical error in the reported NASN data.

A further test is a comparison of the content of elements in the inventory due mainly to coal, coke, and fuel oil combustion with observed particulate composition (Table III). Normalizing to $\mathrm{Cr}=100$, apparently the most accurate value reported by the NASN, the contents of As and $\mathrm{Sn}$ are greater than expected, whereas $\mathrm{Ti}$ is much less than expected. The elements $\mathrm{Ni}$ and $\mathrm{V}$, due mainly to fuel oil and the least reliably known in the published source composition data, are also lower than expected.

Finally, a comparison may be made between key elements for each major source type: $\mathrm{Pb}$ (automotive), Fe (iron and steel), and $\mathrm{Cr}$ (coal, coke, and fuel oil). Table III 
TABLE III

Relative concentrations of elements in air pollution particulates originating mainly from certain sources compared to NASN means of 1964

Element Our inventory Chicago East Chicago Milwankee

A. Elements mainly from the iron and steel industry:

$\begin{array}{lcccc}\mathrm{Fe} & (100) & (100) & (100) & (100) \\ \mathrm{Mn} & 5.4 & 4 & 5 & 6 \\ \mathrm{Cu} & 3.7 & 2.5 & 2 & 3 \\ \mathrm{Zn} & 4.5 & 56 & 47 & 8\end{array}$

B. Elements mainly from coal, coke, and fuel oil combustion:

$\begin{array}{lrccc}\text { As } & 44 & 200 & 120 & 200 \\ \mathrm{Cr} & (100) & (100) & (100) & (100) \\ \mathrm{Sn} & 13 & 140 & 180 & 100 \\ \mathrm{Ti} & 2400 & 140 & 150 & 500 \\ \mathrm{Ni} & 1000 & 300 & 370 & 230 \\ \mathrm{~V} & 610 & 200 & 120 & 40\end{array}$

C. Key elements for three major sources*:

$\begin{array}{ccccc}\mathrm{Pb} & (100) & (100) & (100) & (100) \\ \mathrm{Fe} & 4000 & 180 & 600 & 380\end{array}$

$\begin{array}{lllll}\mathrm{Cr} & 4.5 & 1.6 & 3.7 & 2.0\end{array}$

* $\mathrm{Pb}$ (automotive), $\mathrm{Fe}$ (iron and steel), $\mathrm{Cr}$ (coal, coke, and fuel oil).

indicates $\mathrm{Pb} / \mathrm{Cr}$ predicted by the inventory is close to the observed values in all three locations, but $\mathrm{Fe} / \mathrm{Pb}$ is predicted to be some ten-fold higher than generally observed at the NASN sampling sites. The agreement for $\mathrm{Pb} / \mathrm{Cr}$ is reassuring, for both elements originate in area sources, and the NASN sampling site is expected to be fairly representative for the city in each case. However, bias in sampling against emissions from the ferrous metal industry for Chicago and East Chicago may be considerable and may be the cause of the discrepancy in $\mathrm{Fe} / \mathrm{Pb}$. It is important to look for agreement between calculated and observed element abundances relative to one element whose atmospheric input can be estimated with the greatest reliability, e.g., $\mathrm{Pb}$, as this serves as a criterion for evaluating the reliability of our quantitative elemental inventories.

In a recent study by Dams et al. (1971) of air pollution particulate composition in northwest Indiana (carried out since Table I was prepared) 10 sampling stations distributed throughout the industrialized area and 15 more remote stations were operated for 24 hours on June 11-12, 1969; the filters were analyzed by neutron activation (Dams et al., 1970). The mean of the 10 industrial area stations on this day does not have the location bias of the single NASN station in East Chicago, although only one day of data was obtained for the network. Table IV presents a comparison of the 10 station geometric mean and our inventory adjusted to the observed Fe concentration. Agreement is satisfactory for most elements, including $\mathrm{As}, \mathrm{Ti}$, and $\mathrm{Zn}$ which showed discrepancies in Table III. Consequently, the inventory calculation appears to be considerably better than an order of magnitude estimate of the air pollution elemental source strength of the urban area. 
TABLE IV

Comparison of air particulate contents vs. air pollution inventory

$\left.\begin{array}{lcc}\hline \text { Elements } & \begin{array}{l}\text { Geometric mean of } \\ \text { industrialized } \\ \text { N.W. Indiana } \\ \text { (Stations 1-10) } \\ \text { ng m }\end{array} & \begin{array}{c}\text { Inventory } \\ \text { adjusted to }\end{array} \\ \mathrm{Fe}=6540\end{array}\right)$

\section{Water Pollution from Aerosol Fallout}

To determine whether fallout of air pollution is a significant source of water pollution we must estimate the efficiency of air pollution transfer to the water surface. In constructing a model we should include the following steps: (1) emission from the various sources of the region into the atmosphere to various altitudes depending on the source; (2) local fallout of some components in the immediate vicinity of the source outside the Lake Michigan drainage basin; (3) longer range fallout over the surface of Lake Michigan or its drainage basin. The efficiency of the longer range fallout depends on the wind direction and speed, the altitude at which air pollutants are found, and the effectiveness of removal of the air pollutants from the atmosphere by clear air deposition and precipitation scavenging. We emphasize that quantitative treatment of the model is premature at this time without knowing more precisely the exact locations of sources of each element and details on local winds near specific sources, winds which are affected by lake breezes and which may be important in bringing local fallout from shore-side industries into the lake. Quantitative evaluation of clear air deposition likewise requires knowledge of particle size distributions of trace metals, and precipitation scavenging may also be affected by water solubility of aerosols. At this time we will attempt only to evaluate qualitatively whether overall 
transfer of air pollution to Lake Michigan may be sufficiently large to warrant further consideration of this source of water pollution.

To begin with, although wind directions have not been measured systematically at all pollution sources, data for Midway Airport, Chicago, may serve as a useful guide. The 10 year averages shown in Figure 1 (Managing the Air Resource of North-

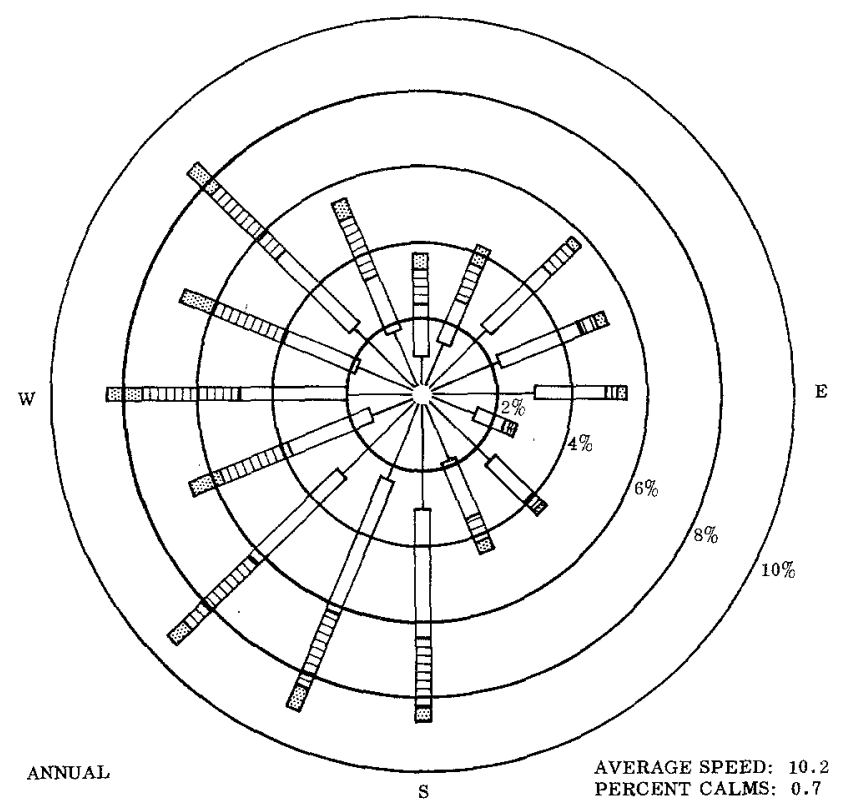

WIND SPEEDS (mph)

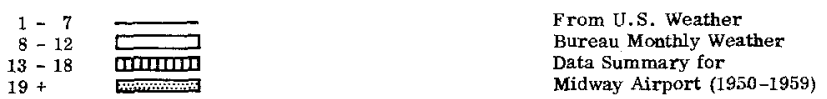

Fig. 1. Percentage frequency of wind direction and speed, Midway Airport, average 1950-1959 (Northeastern Illinois Planning Commission, 1967).

eastern Illinois, 1967) indicate that winds blow from northwest to south over half of the time in a direction generally from the pollution sources toward Lake Michigan. Local wind circulation nearer the lakeshore may be altered by lake breeze effects, but it remains likely that much of the air pollution in this region finds its way to the air over the lake.

The processes of removal of particulates from the atmosphere are intricate and depend, among other factors, on particle size. For Chicago area pollutants, particle size information is not generally available, but we may estimate impaction and gravitational settling to be rapid for some large particle industrial pollutants, e.g. $\mathrm{Fe}$, such that a large fraction of that which is blown toward the lake soon enters the lake. On the other hand, some elements, e.g., $\mathrm{Pb}$, which are components of much 
smaller particles, may enter the lake with a lower efficiency depending on frequency of rainfall or likelihood of impaction with the water surface.

In this connection, the deposition velocity of ${ }^{131} \mathrm{I}$ from the British Windscale nuclear reactor accident has been estimated by Chamberlain (1959) to be 0.3 to 0.4 $\mathrm{cm} \mathrm{s}^{-1}$. Eriksson $(1959,1960)$ estimates $0.7 \mathrm{~cm} \mathrm{~s}^{-1}$ as reasonable for deposition of sea salt aerosols over the open ocean. Both estimates refer to clear air deposition near the ground by all processes for iodine vapors and for giant aerosols having a radius $>1 \mu$, and are determined by taking the ratio of area deposition rate, $\mathrm{g} \mathrm{cm}^{-2} \mathrm{~s}^{-1}$, to air concentration, $\mathrm{g} \mathrm{cm}^{-3}$. Consequently, we may estimate $0.5 \mathrm{~cm} \mathrm{~s}^{-1}$ for average pollution aerosol deposition velocity, implying that particles carried initially to $100 \mathrm{~m}$ altitude near the source would probably reach the water surface in $20000 \mathrm{~s}$ $\left(5.6 \mathrm{hr}\right.$ ). If carried by a $5 \mathrm{~m} \mathrm{~s}^{-1}$ wind, the expected travel distance would be $100 \mathrm{~km}$, a distance close to the mean east-west distance across Lake Michigan. By this simple logic it is not unreasonable to expect a large degree of clear air aerosol fallout over Lake Michigan regardless of particle size. (Additional air scavenging by rainfall may also occur.) To obtain more quantitative estimates, we believe these matters should be explored experimentally, but an overall transfer efficiency of at least $10 \%$ of the original air pollution seems not unlikely.

The significance of air pollution as a source of water pollution cannot be decided until we evaluate inputs of trace elements from other sources, especially streams. Unfortunately, the published literature does not include comprehensive studies of Lake Michigan tributary stream composition with respect to trace metals, but a recent report of the Federal Water Pollution Control Administration (1968) presents stream analyses for $\mathrm{Cu}, \mathrm{Ni}$, and $\mathrm{Zn}$. In Table $\mathrm{V}$ we compare our inventory with their observed concentrations and a calculated total inflow rate based on the composition of each stream and its gaged annual flow rate as given in the report. The air pollution inventories of all three elements $\mathrm{Cu}, \mathrm{Ni}$, and $\mathrm{Zn}$ are in excess of the actual stream inputs and that for $\mathrm{Zn}$ exceeds the stream input 6-fold. Therefore, all three elements (the only ones for which we may make a comparison) may be added to Lake Michigan

TABLE V

Comparison of air pollution inventory with river inflow of trace elements to Lake Michigan, metric units

\begin{tabular}{lrrr}
\hline & $\mathrm{Cu}$ & $\mathrm{Ni}$ & $\mathrm{Zn}$ \\
\hline $\begin{array}{l}\text { Air pollution emissions } \\
\text { inventory, ton yr-1 }\end{array}$ & 3200 & 1000 & 3900 \\
$\begin{array}{l}\text { Lake Michigan rivers approx. mean } \\
\text { conc., 1963-1964, } \mu \mathrm{g} \mathrm{1}^{-1}\end{array}$ & 90 & 40 & 30 \\
$\begin{array}{l}\text { Inflow to Lake Michigan } \\
\text { ton } \mathrm{yr}^{-1 *}\end{array}$ & 2700 & 760 & $\sim 500$ \\
\hline
\end{tabular}

* Estimated for total Lake Michigan drainage basin from contents and flow rates of individual rivers. 
to a great degree from the atmospheric source, especially $\mathrm{Zn}$ which, depending on the actual transfer efficiency, may come primarily from the atmosphere. On the average for all Lake Michigan, $\mathrm{Cu}$ and $\mathrm{Ni}$ apparently do not enter the lake mainly from the atmosphere, but for the southern basin, which lies near the air pollution source and has limited river inflow; the principal sources of these elements may likewise be from air pollution fallout. Data of a similar sort for additional toxic trace elements would be desirable.

It is also of interest to compare air pollution with estimated natural (unpolluted) stream inputs to Lake Michigan. Even though the tributary streams may no longer be unpolluted, Turekian's (1969) compilation of stream data for other locations allows us to estimate expected pre-industrial trace metal inputs to Lake Michigan. Table VI shows the results for those elements included in our inventory. For those marked ' $X$ ' in the last column, air pollution emissions exceed calculated natural water inputs by a factor of 10 ( 8 for $\mathrm{Co}$ ), those marked '?' are in question for reasons apparent from the Table, and $(X)$ signifies one case discussed earlier, Se, where we suspect our inventory underestimates actual emissions by overestimating stack collection efficiency. Compared to natural stream inputs, and assuming an air pollution efficiency of transfer to the lake of $10 \%$, air pollution appears to be an important water pollution source for 7 to 14 of the 31 elements listed. We should point out that the chemical behavior of air pollution fallout into the lake may differ from stream carried material with respect to solubility, sedimentation, and biological activity, and these factors may affect residence times in the water or water and sediment systems.

It is interesting to note (Table $\mathrm{V}$ ) that measured stream inputs of $\mathrm{Cu}$ and $\mathrm{Ni}$ exceed the estimated natural stream inputs (Table VI) by 12 and 76 times, respectively, but $\mathrm{Zn}$ is close to our estimate of its natural stream input. Zinc appears not to be a stream pollutant in the Lake Michigan basin, although overall pollution of the basin by $\mathrm{Zn}$, including that of atmospheric origin, may be considerable.

Finally, another way of looking at our air pollution inventory is to ask how long it would take to raise lake concentrations by an ecologically significant increment through fallout. Again, quantitative treatment of the question must await further data on actual Lake Michigan trace element concentrations, as yet rather sparse, and the effect of trace elements on ecology. However, very crudely we may suggest that 0.1 $\mu \mathrm{g}^{-1}$ is a significant concentration increase for any element. Taking the volume of Lake Michigan to be $4900 \mathrm{~km}^{3}$, and assuming that air pollution enters the lake with $10 \%$ efficiency, we have constructed Table VII for 11 elements. Of these, 8 elements are seen to raise the concentration by the stated amount in times much shorter than $100 \mathrm{yr}$, the mean residence time with respect to water outflow through the Straits of Mackinac. If mean residence times for these elements with respect to sedimentation to the lake bottom are sufficiently long, then as a result of air pollution we may observe an increase in steady state water concentration for these elements. Otherwise, if sedimentation is more rapid than outflow, the pollution component should be manifested in high trace metal concentrations in uppermost lake sediment layers. Further investigation of this question should be carried out. 
TABLE VI

Expected natural stream inputs to Lake Michigan, metric units

\begin{tabular}{|c|c|c|c|c|}
\hline Element & $\begin{array}{l}\text { Stream conc.* } \\
\mu \mathrm{g} 1^{-1}\end{array}$ & $\begin{array}{l}\text { Input }^{+} \\
\text {ton } \mathrm{yr}^{-1}\end{array}$ & $\begin{array}{l}\text { Air pollution } \\
\text { inventory } \\
\text { ton } \mathrm{yr}^{-1}\end{array}$ & $\begin{array}{l}\text { Ratio } \\
\gtrsim 10 ?\end{array}$ \\
\hline $\mathrm{Ag}$ & 0.3 & 10 & 3 & \\
\hline $\mathrm{Al}$ & 400 & 13000 & 45000 & \\
\hline As & 2 & 65 & (44) & ? \\
\hline B & 10 & 330 & 4 & \\
\hline $\mathrm{Ba}$ & 10 & 330 & 210 & \\
\hline $\mathrm{Be}$ & - & - & 5 & ? \\
\hline $\mathrm{Br}$ & 20 & 650 & 725 & \\
\hline $\mathrm{Ca}$ & 15000 & 490000 & 37000 & \\
\hline $\mathrm{Cd}$ & - & - & 12 & $?$ \\
\hline $\mathrm{Cl}$ & 7800 & 250000 & 635 & \\
\hline Co & 0.2 & 6.5 & 50 & $X$ \\
\hline $\mathrm{Cr}$ & 1 & 33 & 100 & \\
\hline $\mathrm{Cu}$ & 7 & 230 & 3200 & $X$ \\
\hline $\mathrm{Fe}$ & $(670)$ & $(22000)$ & 86000 & $?$ \\
\hline $\mathrm{Ga}$ & 0.09 & 3 & $(4.4)$ & \\
\hline K & 2300 & 75000 & 15 & \\
\hline $\mathrm{Mg}$ & 4100 & 134000 & 5500 & \\
\hline $\mathrm{Mn}$ & 7 & 230 & 4600 & $X$ \\
\hline Mo & 1 & 33 & 46 & \\
\hline $\mathrm{Na}$ & 6300 & 200000 & 1400 & \\
\hline $\mathrm{Ni}$ & 0.3 & 10 & 1000 & $X$ \\
\hline $\mathrm{P}$ & 20 & 650 & 150 & \\
\hline $\mathrm{Pb}$ & 3 & 100 & 2200 & $X$ \\
\hline S & 5600 & 180000 & 680000 & \\
\hline $\mathrm{Se}$ & 0.2 & 6.5 & (20) & $(X)$ \\
\hline $\mathrm{Si}$ & 1350 & 44000 & 59000 & \\
\hline Sn & - & - & 13 & ? \\
\hline $\mathrm{Sr}$ & 60 & 2000 & 5 & \\
\hline $\mathrm{Ti}$ & 3 & 100 & 2400 & $X$ \\
\hline V & 0.9 & 29 & 610 & $X$ \\
\hline $\mathrm{Zn}$ & 20 & 650 & 3900 & $X$ \\
\hline
\end{tabular}

* Stream data from Turekian (1969), $1 \mu \mathrm{g}^{-1}=1$ ton $\mathrm{km}^{-3}$

+ Estimated average stream flow into Lake Michigan $=32.6 \mathrm{~km}^{3} \mathrm{yr}^{-1}$.

$\S$ If the ratio air pollution inventory/stream input $\geqslant 10$, there is reason to expect a major input to the lake by the atmospheric route. Such cases are indicated by ' $X$ '; '?' denotes elements where data are lacking or uncertain.

\section{Conclusions}

We have attempted to evaluate (from published information in the literature) whether air pollution along the southwestern shores of Lake Michigan can be a significant source of trace element contamination of the lake. In spite of the extremely fragmentary nature of available data on air and water composition and on meteorological factors, air pollution appears to be an important water pollution source for certain elements. More importantly, this study highlights the need for more comprehensive information in order to formulate exact chemical models for inputs and outputs of contaminants to one of the Great Lakes. 
TABLE VII

\begin{tabular}{lc}
\multicolumn{2}{l}{ Years required to raise Lake Michigan water } \\
concentrations $0.1 \mu \mathrm{g} \mathrm{I}^{-1}$ from fallout of \\
Chicago area air pollution with & $10 \%$ efficiency \\
\hline Element & Years \\
\hline $\mathrm{Cd}$ & 500 \\
$\mathrm{Cr}$ & 55 \\
$\mathrm{Cu}$ & 1.6 \\
$\mathrm{Fe}$ & 0.06 \\
$\mathrm{Mn}$ & 1.1 \\
$\mathrm{Ni}$ & 5.5 \\
$\mathrm{~Pb}$ & 2.4 \\
$\mathrm{Se}$ & 73 \\
$\mathrm{Ti}$ & 2.5 \\
$\mathrm{~V}$ & 9 \\
$\mathrm{Zn}$ & 1.3 \\
\hline
\end{tabular}

\section{Appendix}

\section{DETAILS OF THE ELEMENTAL EMISSIONS INVENTORY CALCULATION}

The consumption of coal, fuel oil, and automotive fuel in the region of interest here is assumed to be $4 \%$ of the national consumption, in proportion to the estimated 1969 population of the region, where total U.S. annual consumption is estimated by the World Almanac and Book of Facts (1967) as: coal, 540 million short tons* (not including coal for coke production); fuel oil, 1200 million barrels (200 million short tons); automotive fuel, 830 gallons per year by each of 95 million automobiles (79 billion gallons). Coke production is estimated to be $21 \%$ of the national production of 77 million tons, based on the fraction of total U.S. iron and steel produced in the region (Raw Steel Production, 1968). Emissions from blast furnaces, sinter plants, open hearth furnaces, and basic oxygen furnaces (Raw Steel Production, 1968) as well as cement plant emissions (Kreichelt et al., 1967), are based on production figures for the region. It should be pointed out that emissions based on production figures and listed in this report are conservative; that is, emissions from major sources were considered but not inputs from minor sources, e.g., chemical industry, galvanizing, tinning, and trash.

The best available information on the composition of particulate emission from coal combustion appears to be contained in two recent reports of the U.S. Public Health Service (Smith and Gruber, 1966; Cuffe and Gerstle, 1967). For some common elements analyses of fly ash itself are presented (Smith and Gruber, 1966) but for the less common elements the data are presented (Cuffe and Gerstle, 1967) as grains of the element per standard cubic foot of flue gas for several types of boiler firing. The same references presents the total amount of fly ash in the same units, as well as further data, which permits an estimate of emissions to be calculated as approximately

* Because source data are available only in the English system of units, calculations have been carried out largely in terms of short tons of 2000 pounds ( 0.907 metric ton). 
20 pounds of fly ash per short ton of coal used in electric power production, and 25 pounds of fly ash per short ton of coal burned for purposes other than generation of electricity. The weighted average is about 22 pounds of fly ash per short ton of coal consumed as a mean of the types of boiler firings considered. Fly ash emitted to the atmosphere comprises about $10 \%$ of the total ash produced. Table VIII summarizes

TABLE VIII

Composition of particulate emission from coal combustion

\begin{tabular}{|c|c|c|c|}
\hline Element & $\begin{array}{l}\text { Parts per } \\
\text { thousand }\end{array}$ & Element & $\begin{array}{l}\text { Parts per } \\
\text { thousand }\end{array}$ \\
\hline $\mathrm{Al}$ & 140 & $\mathrm{Mn}$ & 0.24 \\
\hline As & 0.16 & Mo & 0.16 \\
\hline $\mathrm{Ba}$ & 0.6 & $\mathrm{Na}$ & 4 \\
\hline $\mathrm{Be}$ & 0.018 & $\mathrm{Ni}$ & 0.4 \\
\hline $\mathrm{Ca}$ & 40 & $\mathrm{~Pb}$ & 1.2 \\
\hline $\mathrm{Cd}$ & 0.04 & $\mathrm{Se}$ & 0.02 \\
\hline Co & 0.09 & $\mathrm{Si}$ & 200 \\
\hline $\mathrm{Cr}$ & 0.3 & Sn & 0.05 \\
\hline $\mathrm{Cu}$ & 0.4 & $\mathrm{Ti}$ & 9 \\
\hline $\mathrm{Fe}$ & 70 & V & 0.8 \\
\hline $\mathrm{Mg}$ & 8 & $\mathrm{Zn}$ & 0.9 \\
\hline
\end{tabular}

calculations of the composition of particulate emission from coal combustion using this information. The selenium content is estimated by assuming $2.4 \%$ sulfur in the coal, a ratio Se $/ \mathrm{S}=10^{-4}$ (Hashimoto and Winchester, 1967; Thomas, 1969), and $10 \%$ of the Se appearing in the particulate emission, in line with an assumed $90 \%$ collection efficiency. (Se emissions may exceed this estimate since the expected compound, $\mathrm{SeO}_{2}$, is a vapor above $315^{\circ} \mathrm{C}$.) Coke oven emissions are assumed to have the same relative elemental composition as the particulates from coal combustion and are estimated to be 20000 short tons per year, 1.5 times the value published for northwest Indiana alone (Ozolins and Rehmann, 1968).

Table IX represents very roughly the composition of particulate emissions from fuel combustion, based on two tests reported (Smith, 1967) and an assumed value of $\mathrm{Se} / \mathrm{S}=10^{-4}$, although the elemental composition varies widely with the source of the crude oil. The reported value (Duprey, 1968) of $0.2 \%$ of the weight of fuel oil burned which appears as airborne particulates is taken, or 16000 short tons of particulate from this source per year in the region.

Calculations of trace elements in particulate emissions for the iron and steel industry require a detailed examination of the several sources involved, and the considerations which went into such calculations include the following:

In the nation, approximately 82 million short tons of pig iron per year are produced from iron ore, coke, and limestone, and 130 million tons of raw steel are produced (Raw Steel Production, 1968; Schueneman et al., 1963). Very nearly $21 \%$ of the steel, or 27 million tons, is made in the Chicago and northwestern Indiana area. Thus it 
TABLE IX

Composition of particulate emission from fuel oil combustion

\begin{tabular}{lcccc}
\hline Element & $\begin{array}{c}\text { Parts per } \\
\text { thousand }\end{array}$ & & Element & $\begin{array}{c}\text { Parts per } \\
\text { thousand }\end{array}$ \\
\hline $\mathrm{Al}$ & 50 & & $\mathrm{Mn}$ & 0.3 \\
$\mathrm{Ag}$ & 0.20 & & $\mathrm{Mo}$ & 0.2 \\
$\mathrm{~B}$ & 0.25 & & $\mathrm{Na}$ & 15 \\
$\mathrm{Ba}$ & 2.5 & & $\mathrm{Ni}$ & 60 \\
$\mathrm{Ca}$ & 4 & & $\mathrm{~Pb}$ & 1.8 \\
$\mathrm{Co}$ & 1.5 & & $\mathrm{Se}$ & 1.0 \\
$\mathrm{Cr}$ & 1.2 & & $\mathrm{Si}$ & 24 \\
$\mathrm{Cu}$ & 1.6 & $\mathrm{Sr}$ & 0.3 \\
$\mathrm{Fe}$ & 25 & & $\mathrm{Ti}$ & 0.3 \\
$\mathrm{~K}$ & 1.0 & & $\mathrm{~V}$ & 25 \\
$\mathrm{Mg}$ & 3 & & $\mathrm{Zn}$ & 0.5 \\
\hline
\end{tabular}

was assumed that $21 \%$ of total pig iron was also produced in the area, or 17 million tons. About $\frac{2}{3}$ of this area production actually arises from plants in northwestern Indiana, and $\frac{1}{3}$ from plants in northeastern Illinois (World Almanac and Book of Facts, 1967; Raw Steel Production, 1968).

Emissions from blast furnaces during pig iron production are fairly well controlled, but about 13000 tons/year are emitted for the entire area (Duprey, 1968; Ozolins and Rehmann, 1968) as a minimum. Emissions from sinter plants are considerably higher and were arrived at by separate methods for northwestern Indiana and the remainder of the study area. Sinter plant emissions for northwestern Indiana have been published by Ozolins and Rehmann (1968); sinter plant emissions for Chicago were calculated from the tons of iron processed, and an emission of 3.5 pounds particulate emitted per ton processed (Duprey, 1968). Thus, yearly atmospheric emissions of 88000 tons from northwestern Indiana sinter production and 10000 tons from Chicago sinter plants were obtained, for a total of approximately 100000 tons. Table $\mathrm{X}$ gives the composition of emissions from sinter plants and blast furnaces (Sebesta, 1968).

Regarding the production of raw steel, about half is made in open hearth furnaces, and, although a small amount is produced in electric furnaces, it was assumed for purposes of calculation that half is made in the basic oxygen furnace. Again, particulate emissions for northwestern Indiana were available for both processes (Ozolins and Rehmann, 1968) 67000 tons from the open hearth and 500 tons from the basic oxygen furnace (BOF). In northeast Illinois, emissions from steel manufacturing had to be calculated from tons of product (Schueneman et al., 1963; Duprey, 1968). Assuming that emission control devices are in operation, 7.5 pound-ton ${ }^{-1}$ are emitted from the open hearth process, and 0.4 pound-ton $^{-1}$ from the BOF, or, per year, 17000 tons from the open hearth and 1000 tons from the BOF for northeastern Illinois. Thus

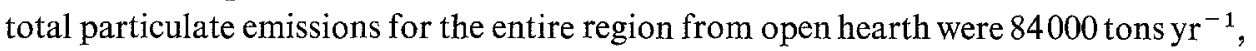
and from BOF, 1500 tons $\mathrm{yr}^{-1}$. Elemental composition of open hearth and BOF emissions (Schueneman et al., 1963) are also given in Table X. 
TABLE X

Composition of particulate emission from the iron and steel industry

\begin{tabular}{|c|c|c|c|}
\hline \multirow[t]{2}{*}{ Element } & \multicolumn{3}{|c|}{ Contents in parts per thousand } \\
\hline & $\begin{array}{l}\text { Blast furnaces and } \\
\text { sinter plants }\end{array}$ & $\begin{array}{l}\text { Open hearth } \\
\text { furnaces }\end{array}$ & $\begin{array}{l}\text { Basic oxygen } \\
\text { furnaces }\end{array}$ \\
\hline Al & 35 & 12 & 11 \\
\hline $\mathrm{Ca}$ & 90 & 17 & 12 \\
\hline $\mathrm{Cu}$ & 30 & & \\
\hline $\mathrm{Fe}$ & 220 & 560 & 570 \\
\hline $\mathrm{Mg}$ & 20 & 13 & 3 \\
\hline Mn & 35 & 12 & 31 \\
\hline $\mathbf{P}$ & & 2 & 1 \\
\hline $\mathrm{Si}$ & & 10 & 7 \\
\hline $\mathrm{Zn}$ & 35 & & \\
\hline
\end{tabular}

Particulate emissions from the manufacturing of portland cement could be conservatively estimated as 40000 ton $\mathrm{yr}^{-1}$, based on production figures for the area (Kreichelt et al., 1967). This corresponds to about 13 pounds of dust emitted per ton of cement produced. Of this total, about 27000 tons of dust are emitted per year in northwestern Indiana (Ozolins and Rehmann, 1968). The emission was assumed to have the same approximate composition as the finished product (Schueneman et al., 1963), viz. $2.5 \% \mathrm{Al}, 44 \% \mathrm{Ca}, 2.7 \% \mathrm{Fe}, 1.2 \% \mathrm{Mg}$, and $10 \% \mathrm{Si}$.

The emissions of five elements were estimated from burning leaded gasoline in internal combustion engines. The number of gallons of gasoline consumed in the study area was estimated from the U.S. Bureau of the Census (1961) regarding number of motor vehicles and annual gasoline consumption per vehicle (Duprey, 1968). Sulfur and selenium emissions could be calculated as 7000 ton $\mathrm{yr}^{-1}$ (Duprey, 1968) and 1 ton $\mathrm{yr}^{-1}$ (Hashimoto and Winchester, 1967; Thomas, 1969), respectively. Lead, chlorine, and bromine emissions could be calculated as 2000 tons $\mathrm{yr}^{-1}, 700$ ton $\mathrm{yr}^{-1}$, and 800 ton $\mathrm{yr}^{-1}$, respectively, assuming that $25 \%$ of the lead and halogen product eventually becomes airborne (Working Group on Lead Contaminants, 1965). These results assume contents in grams per gallon: $\mathrm{Br} 0.8, \mathrm{Cl} 0.7, \mathrm{~Pb} 2, \mathrm{~S} 2, \mathrm{Se} 0.0002$.

\section{Acknowledgement}

Contribution No. 161 from the Department of Meteorology and Oceanography and No. 110 from the Great Lakes Research Division, University of Michigan. Supported in part by USAEC contract AT (11-1)-1705 and by a USPHS air pollution traineeship for one of us (G.D.N.)

\section{References}

Air Quality Data from the National Air Sampling Networks and Contributing State and Local Networks, 1964-1965: 1966, Division of Air Pollution, Public Health Service, U.S. Dept. of Health, Education, and Welfare, Cincinnati, Ohio.

Bacon, V. W. and Dalton, F. E.: 1968, J. Water Pollut. Contr. Fed. 40, 1586. 
Chamberlain, A. C.: 1959, Quart. J. Roy. Meteorol. Soc. 85, 350.

Cuffe, S. T. and Gerstle, R. W.: 1967, Emissions from Coal-Fired Power Plants: A Comprehensive Summary, Publ. No. 999-AP-35, National Center for Air Pollution Control, U.S. Dept. of Health, Education, and Welfare, Cincinnati, Ohio.

Dams, R., Robbins, J. A., Rahn, K. A., and Winchester, J. W.: 1970, Anal. Chem. 42, 861.

Dams, R., Robbins, J. A., Rahn, K. A., and Winchester, J. W.: 1971, Nuclear Techniques in the Measurement and Control of Environmental Pollution, International Atomic Energy Agency, Vienna.

Duprey, R. L.: 1968, Compilation of Air Pollutant Emission Factors, Publ. No. 999-AP-42, National Center for Air Pollution Control, U.S. Dept. of Health, Education, and Welfare, Durham, N.C.

Encyclopaedia Britannica: 1968, 5, 153.

Eriksson, E.: 1959, Tellus 11, 375.

Eriksson, E.: 1960, Tellus 12, 63.

Hashimoto, Y. and Winchester, J. W.: 1967, Environ. Sci. Technol. 1, 338.

Kreichelt, T. E., Kemnitz, D. A., and Cuffe, S. T.: 1967, Atmospheric Emissions from the Manufacture of Portland Cement, Publ. No. 999-AP-17, National Center for Air Pollution Control, U.S. Dept. of Health, Education, and Welfare, Cincinnati, Ohio.

Managing the Air Resource of Northeastern Illinois: 1967, Technical Rep. No. 6, Northeastern Illinois Planning Commission, Chicago, August.

Ozolins, G. and Rehmann, C.: 1968, Air Pollutant Emission Inventory of Northwest Imdiana, A Preliminary Survey, 1966, Publ. No. APTD-68-4, National Center for Air Pollution Control, U.S. Dept. of Health, Education, and Welfare, Durham, N.C.

'Raw Steel Production', from 'Market Outlook', Steel, 163.

Schueneman, J. J., High, M. D., and Bye, W. E.: 1963, Air Pollution Aspects of the Iron and Steel Industry, Publ. No. 999-AP-1, Division of Air Pollution, Public Health Service, U.S. Dept. of Health, Education, and Welfare, Cincinnati, Ohio.

Sebesta, W.: 1968, in Air Pollution, (ed. by A. C. Stern) III, 143, Academic Press, New York.

Smith, W. S.: 1962, Atmospheric Emissions from Fuel Oil Combustion, An Inventory Guide, Publ. No. 999-AP-2, Division of Air Pollution, Public Health Service, U.S. Dept. of Health, Education, and Welfare, Cincinnati, Ohio.

Smith, W. S. and Gruber, C. W.: 1966, Atmospheric Emissions from Coal Combustion - An Inventory Guide, Publ. No. 999-AP-24, Division of Air Pollution, U.S. Public Health Service, U.S. Dept. of Health, Education, and Welfare, Cincinnati, Ohio.

Thomas, C.: 1969, unpublished data from the Western New York Nuclear Research Center, Buffalo, N.Y.

Turekian, K. K.: 1969, 1969 Yearbook of Science and Technology, McGraw-Hill, New York.

U.S. Bureau of the Census: 1961, U.S. Censuses of Population and Housing: 1960, Census Tracts, U.S. Governm. Printing Office Washington, D.C.

Water Quality Investigations, Lake Michigan Basin, Physical and Chemical Quality Conditions: 1968, U.S. Dept. of the Interior, Federal Water Pollution Control Administration, Chicago, January.

Working Group on Lead Contamination: 1965, Survey of Lead in the Atmosphere of Three Urban Communities, Publ. No. 999-AP-12, Division of Air Pollution, Public Health Service, U.S. Dept. of Health, Education, and Welfare, Cincinnati, Ohio.

World Almanac and Book of Facts 1968: 1967, Newspaper Enterprise Assoc. Inc., New York. 